\title{
Molecular characterization of two bacteriophages isolated from Desulfovibrio vulgaris NCIMB 8303 (Hildenborough)
}

\author{
S. Seyedirashti, C. Wood* and J. M. Akagi \\ Department of Microbiology, University of Kansas, Lawrence, KS 66045, USA
}

(Received 16 March 1992; accepted 7 April 1992)

\begin{abstract}
A preliminary endonuclease restriction map of a bacteriophage isolated from Desulfovibrio vulgaris has been established. BamHI cleaved whole phage DNA into four fragments while HindIII cut the same DNA into seven fragments. Mapping studies succeeded in linking the four BamHI fragments into two DNA segments; however, no linkage between the two segments was detected. These data imply that two phages were induced from cultures of $D$. vulgaris and that the two segments represented the DNA from these phages. Support for this hypothesis came from size approximation of restriction enzyme fragments, electron micrographs, and density gradients.
\end{abstract}

\section{Introduction}

Bacteriophages are natural vehicles of genetic transfer. However, relatively little is known about the bacteriophages found in sulphate-reducing bacteria (SRB). Handley et al. (1973) reported bacteriophage-like particles induced from cultures of Desulfovibrio vulgaris NCIMB 8303 by UV radiation or treatment with mitomycin $\mathrm{C}$. The phages have a hexagonal head and a long contractile tail (Handley et al., 1973) and were morphologically similar to Bradley's group A bacteriophages (Bradley, 1967). Recently bacteriophages were found in two other species of Desulfovibrio. Rapp \& Wall (1987) reported that in $D$. desulfuricans ATCC 27774, genetic transfer of rifampicin resistance was mediated by a phage by a generalized transduction mechanism. This phage is not inducible with mitomycin $\mathrm{C}$ and is morphologically distinct from the $D$. vulgaris phage. The third Desulfovibrio phage was identified in a halophilic SRB, D. salexigens NCIMB 8308 by Kamimura \& Araki (1989); it was morphologically similar to the phage induced from $D$. vulgaris with the exception that the tail is ron-contractile.

Besides morphological characterizations of these phages, a paucity of information exists concerning molecular biological analyses of these viruses because of difficulties in propagating and isolating them. By optimizing the conditions for inducing and isolation of a $D$. vulgaris bacteriophage we have succeeded in producing microgram quantities of phage DNA sensitive to

* Author for correspondence. Tel. (913) 8644311. restriction enzyme digestion. This showed the phage DNA to be double stranded (Seyedirashti et al., 1991). This study reports the restriction endonuclease mapping of DNA from phage induced from $D$. vulgaris. The findings imply that there are two different prophages present in $D$. vulgaris.

\section{Methods}

Growth and maintenance of cultures. Desulfovibrio vulgaris NCIMB 8303 (Hildenborough) was maintained on Postgate's medium C (Postgate, 1984) and routinely checked for purity according to Postgate (1984). Ten millilitres of $24 \mathrm{~h}$ cultures were transferred to $200 \mathrm{ml}$ medium $\mathrm{C}$ in $300 \mathrm{ml}$ Florence flasks and incubated under a $\mathrm{K}_{2} \mathrm{CO}_{3}$ /pyrogallol seal.

Induction of bacteriophages. A $120 \mathrm{ml}$ volume of 8-h-old cultures was irradiated for $1 \mathrm{~min}$ with ultraviolet light $(15 \mathrm{~W}$ General Electric Germicidal Lamp) in a $30 \times 20.5 \mathrm{~cm}$ stainless steel pan with gentle agitation. The UV source dosage was $0.8 \mathrm{Jm}^{2}(40 \mathrm{~cm})$. The culture was then incubated anaerobically for $12 \mathrm{~d}$ at $37^{\circ} \mathrm{C}$, after which time the cultures were harvested for bacteriophages.

Purification of bacteriophages and extraction of DNA. Concentration of phage particles and extraction of DNA were performed using a modified procedure of Maniatis et al. (1982). After $12 \mathrm{~d}$ incubation of the induced cultures, the culture medium was centrifuged at $5000 \mathrm{~g}$ for $30 \mathrm{~min}$. The supernatant fraction was supplemented with RNAase A and DNAase $\mathrm{I}$, to give a final concentration of $1 \mu \mathrm{g} \mathrm{ml}^{-1}$ for each enzyme and incubated at $37^{\circ} \mathrm{C}$ for $30 \mathrm{~min}$. Polyethylene glycol and $\mathrm{NaCl}$ were added to final concentrations of $10 \%(\mathrm{w} / \mathrm{v})$ and $1 \mathrm{M}$, respectively, and the phage particles were allowed to precipitate at $4{ }^{\circ} \mathrm{C}$ overnight. The precipitated phage particles were centrifuged at $10000 \mathrm{~g}$ for $20 \mathrm{~min}$ and suspended in $1 \mathrm{ml} \mathrm{TM}$ (10 mM-Tris/ $\mathrm{HCl}$ buffer, pH 8.0, 10 mM- $\mathrm{MgSO}_{4}$ ). Phage DNA was extracted by the addition of SDS and EDTA to give final concentrations of $1 \%(\mathrm{w} / \mathrm{v})$ and $10 \mathrm{mM}$, respectively, followed by phenol/chloroform $(1: 1)$ extraction and 
dialysis against TE buffer (10 mM-Tris/HCl, pH 7.6, 1 mM-EDTA). The DNA concentration was determined by measuring $A_{260}$.

For large-scale preparations of phage DNA, the phage particles were purified using a three-step $\mathrm{CsCl}$ gradient $\left(1.3,1.5\right.$ and $\left.1.7 \mathrm{~g} \mathrm{ml}^{-1}\right)$. The gradient was centrifuged at 37000 r.p.m. in a Beckman SW-41 rotor for $1.5 \mathrm{~h}$ at $18^{\circ} \mathrm{C}$. The phage band was collected, dialysed against TM, and stored at $4{ }^{\circ} \mathrm{C}$. Phage DNA was extracted as described above and further purified by centrifugation at 45000 r.p.m. (Beckman $50 \mathrm{Ti}$ rotor) for $36 \mathrm{~h}$ at $18{ }^{\circ} \mathrm{C}$ in $\mathrm{CsCl}$ solution $\left(1.5 \mathrm{~g} \mathrm{ml}^{-1}\right)$ containing ethidium bromide $\left(125 \mu \mathrm{g} \mathrm{ml}^{-1}\right)$. The DNA band was collected with a syringe and needle and the ethidium bromide was extracted with isoamyl alcohol saturated with $\mathrm{CsCl}$. The DNA preparation was dialysed against TE buffer.

Cloning and analyses of bacteriophage DNA. Manipulations of nucleic acids such as restriction enzyme treatment, Southern blot hybridization and subcloning of DNA segments were performed using standard methods described by Maniatis et al. (1982). The cosmid vector pJB8, used for subcloning of the phage DNA segments was kindly provided by Dr Ish-Horowicz (Ish-Horowicz \& Burke, 1981).

Electron microscopy. For visualization of phage DNA, the nonaqueous (formamide) procedure was used (Garon, 1986; Westmoreland et al., 1969). A stock spreading solution $(700 \mu$ l deionized formamide; $100 \mu \mathrm{l}$ Tris/ $\mathrm{HCl} \mathrm{pH} 8.0 ; 50 \mu \mathrm{l} 5 \mathrm{M}-\mathrm{NaCl} ; 20 \mu \mathrm{l} 0.5 \mathrm{M}-$ EDTA and $130 \mu 1$ deionized water) was prepared. Nucleic acid $(8 \mu 1$ containing $\left.1-5 \mu \mathrm{g} \mathrm{ml}^{-1}\right)$ and cytochrome $c\left(1 \mu \mathrm{lof}\right.$ a $1 \mathrm{mg} \mathrm{ml}^{-1}$ solution $)$ were added to $40 \mu \mathrm{l}$ stock spreading solution. A drop of this preparation was pipetted down a clean glass slide onto the surface of a hypophase $(20 \%, \mathrm{v} / \mathrm{v}$, formamide; $10 \mathrm{mM}$-Tris $\mathrm{HCl}, \mathrm{pH} 8.5 ; 1$ mM-EDTA $)$ that completely filled a plastic Petri dish. The resulting monolayer was immediately transferred to a parlodion-coated grid by gently touching it to the hypophase surface. The grid was stained with uranyl acetate for $30 \mathrm{~s}$ and destained with $90 \%(\mathrm{v} / \mathrm{v})$ ethanol for $10 \mathrm{~s}$. After the grid was air-dried, it was rotary shadowed with platinum-palladium $(80: 20)$ at an angle of $6-10^{\circ}$. The grid was examined with a Philips EM 300 electron microscope.

\section{Results and Discussion}

\section{Restriction analyses of D. vulgaris NCIMB 8303 bacteriophage}

The restriction enzyme pattern of the purified phage DNA digested with BamHI is shown in Fig. $1($ a), lane 2. The sizes of the four bands were estimated to be $>25$, $21.9,18.8$ and $6.6 \mathrm{~kb}$, and designated as $\mathrm{Ba}, \mathrm{Bb}, \mathrm{Bc}$ and $\mathrm{Bd}$, respectively. No additional fragments were detected even when phage DNA was radioactively labelled to enhance the detection of small fragments. Digestion with $H$ indIII appeared to produce seven fragments (Fig. $1 b$, lane 2, and Fig. $1 c$, lane 2) estimated to be $25,13 \cdot 5,5 \cdot 8$, $3 \cdot 7,3 \cdot 3,2 \cdot 1$ and $1.8 \mathrm{~kb}$ in size, and designated as $\mathrm{Ha}, \mathrm{Hb}$, $\mathrm{Hc}, \mathrm{Hd}, \mathrm{He}, \mathrm{Hf}$ and $\mathrm{Hg}$, respectively. The top two bands, 25 and $13.5 \mathrm{~kb}$, are much more intense than the smaller bands. In order for the smaller bands to show up clearly in the gel, more DNA had to be used for analysis. Comparing Fig. $1(b)$, lane 2 and Fig. $1(c)$, lane 2, about three times as much DNA was used in Fig. $1(c)$. The $13.5 \mathrm{~kb}$ band appears to be diffuse; it is possible that
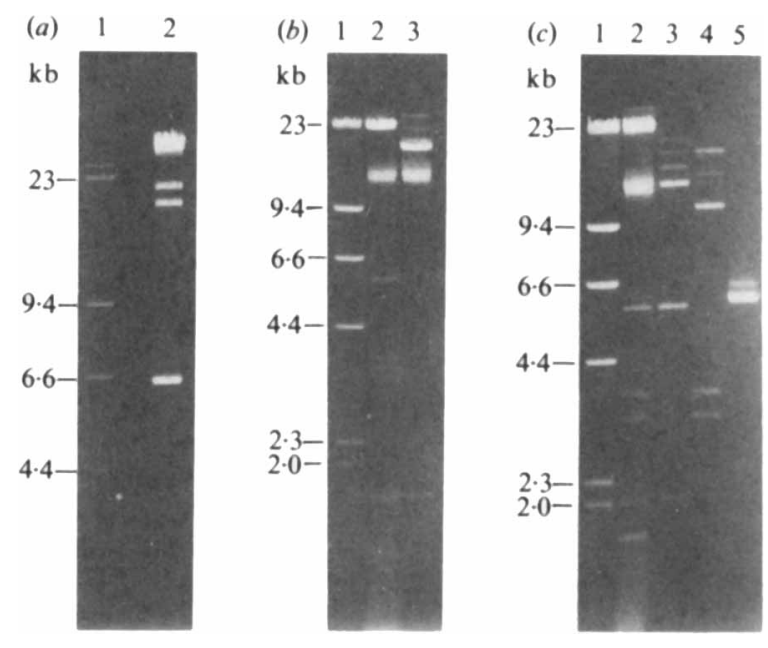

Fig. 1. HindIII digestion pattern of BamHI fragments of phage DNA from $D$. vulgaris. The BamHI digestion pattern of phage DNA is shown in (a), lane 2. The HindIII digestion pattern of total phage DNA is shown in lane 2 of $(b)$ and $(c)$. The BamHI fragments of phage DNA were recovered by electroelution and then digested with HindIII. (b) Lane 3 is the HindIII restriction of the Ba fragment. (c) Lanes 3, 4 and 5 are HindIII restrictions of $\mathrm{Bb}, \mathrm{Bc}$ and $\mathrm{Bd}$, respectively. HindIIIdigested $\lambda$ phage DNA is shown in lane 1 of each panel.

there may be a protein or carbohydrate tightly bound to this DNA fragment which may result in the fuzzy appearance in the gel. The sum of the HindIII fragments was calculated to be approximately $55 \mathrm{~kb}$, while the size of the phage genome estimated by BamHI digestion was over $72 \mathrm{~kb}$.

\section{Mapping of the phage genome}

To map the HindIII sites on each BamHI fragment, phage DNA was digested with BamHI and each of the four $B a m H I$ fragments was extracted from a preparative agarose gel after electrophoresis. Each individual fragment was isolated and digested with HindIII, and the patterns were compared to the pattern of the whole phage DNA digested with the same enzyme. The results are shown in Fig. $1(b)$ and $(c)$. For the Ba fragment (Fig. $1 b$, lane 3 ), digestion with HindIII gave three bands of $18.5,13.5$ and $1.8 \mathrm{~kb}$. The faint bands above the $18.5 \mathrm{~kb}$ fragment are probably due to partial digestion of the DNA. The migration of the 13.5 and $1.8 \mathrm{~kb}$ fragments on agarose gel was identical to the $\mathrm{Hb}(13.5 \mathrm{~kb})$ and the $\mathrm{Hg}$ $(1.8 \mathrm{~kb})$ bands resulting from the digestion of the phage DNA by HindIII (Fig. 1b, lane 2). To confirm that they were the same fragments, the $\mathrm{Ba}$ fragment was radiolabelled and hybridized to phage DNA digested with HindIII. Three different fragments hybridized with labelled Ba fragment. The $\mathrm{Hb}(13.5 \mathrm{~kb})$ and $\mathrm{Hg}(1.8 \mathrm{~kb})$ fragments hybridized as expected, but in addition, the 
(a)

Cloned Hal

(b)

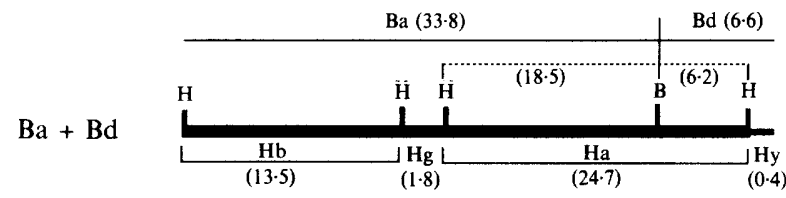

(c) $\mathrm{Bb}+\mathrm{Bc}$

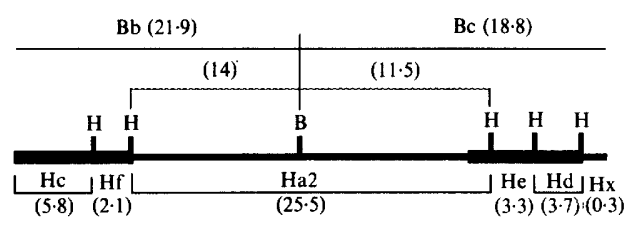

Fig. 2. Proposed arrangement of HindIII and BamHI fragments of phage DNA from $D$. vulgaris. Restriction enzymes are abbreviated as BamHI (B) and HindIII (H). (a) Schematic representation of the Hal fragment cloned in pJBB. (b) Linkage map of $\mathrm{Ba}$ and $\mathrm{Bd}$ fragments. (c) Assumed linkage map of $\mathrm{Bb}$ and $\mathrm{Bc}$ fragments.

$\mathrm{Ha}$ (approximately $25 \mathrm{~kb}$ ) fragment hybridized with the $\mathrm{Ba}$ fragment. This implied that the $18.5 \mathrm{~kb}$ fragment was part of a larger phage HindIII fragment (Ha) that contained a BamHI site. The map of the Ba fragment is shown in Fig. 2(b). Similarly the other BamHI fragments $(\mathrm{Bb}, \mathrm{Bc}, \mathrm{Bd})$ of the phage DNA were digested with HindIII (Fig. 1c) and confirmed by hybridization as described for the $\mathrm{Ba}$ fragment. Interestingly, all four $\mathrm{Ba}$ fragments hybridized to the $25 \mathrm{~kb}$ Ha band, implying that there may be more than one fragment in the $25 \mathrm{~kb}$ band. The mapping of the HindIII sites on the four BamHI fragments is shown in Fig. 2.

For the $\mathrm{Ba}$ fragment, it is not clear whether the HindIII site is located exactly at the end of the $\mathrm{Ba}$ fragment (Fig. 2b). However, the existence of this HindIII site was confirmed by subcloning the $\mathrm{Hb}$ fragment directly into the HindIII site of a plasmid. It is possible that a very small oligonucleotide fragment, which we did not detect, may indeed exist $5^{\prime}$ to the HindIII site at the $5^{\prime}$ end of the $\mathrm{Ba}$ fragment.

To establish the orders of the HindIII sites within the BamHI fragments, two approaches were used. First, each isolated BamHI fragment was end-labelled and then cut with HindIII, which enabled us to identify the end fragments. For example, when the $18.8 \mathrm{~kb}(\mathrm{Bc})$ fragment was labelled and cut with HindIII (Fig. 2), the $11.5 \mathrm{~kb}$ and a small $0.3 \mathrm{~kb}(\mathrm{Hx})$ fragments were labelled whilst the $3.3(\mathrm{He})$ and $3.7 \mathrm{~kb}(\mathrm{Hd})$ fragments were not, indicating that the latter two fragments ( $\mathrm{Hd}$ and $\mathrm{He}$ ) were internal. Similar end-labelling experiments were performed on the other BamHI fragments and the orders of most of the HindIII sites within the BamHI fragments were determined (Fig. $2 b, c$ ). To confirm these results, total phage DNA was partially digested with HindIII and then hybridized with various cloned fragments in

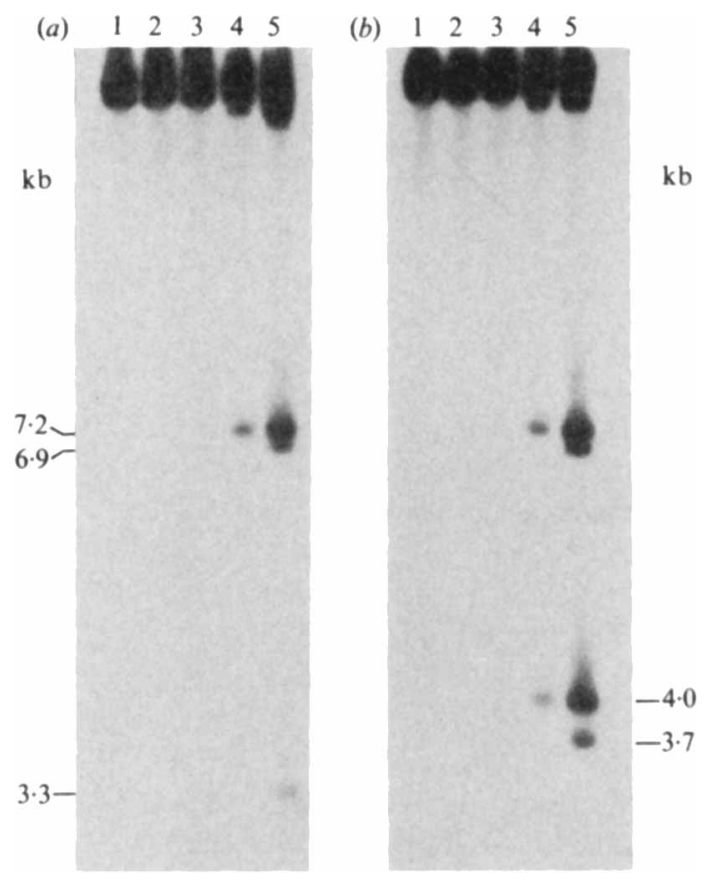

Fig. 3. Southern blot hybridization of $\mathrm{He}(a)$ and $\mathrm{Hd}(b)$ fragments with partial HindIII-digested bacteriophage DNA. He and $\mathrm{Hd}$ fragments of phage DNA were cloned into pUC13, amplified, cut out of pUC13 with HindIII, electrophoresed on agarose gel, electroeluted, nicktranslated and hybridized to partial HindIII-digested phage DNA. Bacteriophage DNA in both panels was digested with $1: 3$ serial dilutions of HindIII, starting with 12 units of enzyme, shown in lanes 1-5 (lane 5 contained 12 units).

order to elucidate the HindIII sites within the BamHI fragments. An example of one of these experiments with the $18.8 \mathrm{~kb}(\mathrm{Bc})$ fragment is shown in Fig. 3. Total phage DNA was partially digested with increasing amounts of HindIII so that lower concentrations of enzyme digested the DNA partially and the higher concentrations of enzyme digested the DNA completely. The digested DNA was then hybridized to either the $3.3(\mathrm{He})$ or 3.7 (Hd) fragment (Fig. 2c) that was subcloned into a pUC13 vector. Fig. $3(a)$ shows that the He probe hybridized to its $3.3 \mathrm{~kb}$ counterpart as expected. In addition, it also hybridized to two partially digested 6.9 and $7.2 \mathrm{~kb}$ bands. This implied that the $6.9 \mathrm{~kb}$ band consisted of $\mathrm{Hd}$ $(3.7 \mathrm{~kb})$ plus $\mathrm{He}(3.3 \mathrm{~kb})$ while the $7.2 \mathrm{~kb}$ band contained three fragments, $\mathrm{Hd}, \mathrm{He}$ and $\mathrm{Hx}$ and, furthermore, that the $\mathrm{Hx}$ band must be the $0.3 \mathrm{~kb}$ fragment which constituted the end of the $\mathrm{Bc}$ fragment. Since the results from the hybridization with the $\mathrm{He}(3.3 \mathrm{~kb})$ fragment (Fig. $3 a$ ) did not provide evidence that $\mathrm{Hx}$ was connected to $\mathrm{Hd}$ or $\mathrm{He}$, a hybridization experiment was done with partially digested phage DNA with $\mathrm{Hd}$ $(3.7 \mathrm{~kb})$ as the probe. The results (Fig. $3 b$ ) show that $\mathrm{Hd}$ hybridized with its counterpart band $(3.7 \mathrm{~kb})$, the $6.9 \mathrm{~kb}$ $(\mathrm{He}+\mathrm{Hd})$ and $7.2 \mathrm{~kb}(\mathrm{He}+\mathrm{Hd}+\mathrm{Hx})$ bands. In addi- 
tion, it also hybridized with a $4 \mathrm{~kb}$ band that was not observed when the He probe was used (Fig. $3 a$ ). These data indicated that $\mathrm{Hx}(0.3 \mathrm{~kb})$ is connected to the $\mathrm{Hd}$ fragment as shown in Fig. 2(c), which accounts for the $4 \mathrm{~kb}$ band that hybridized with the Hd probe. In this way the HindIII sites were mapped on the Bc fragment. Similar partial digestions and hybridizations were performed with all the other BamHI fragments to establish the map shown in Fig. 2.

To link the four BamHI fragments of the phage, a BamHI-HindIII double digestion approach was used to identify all new fragments that were generated after double digestion, i.e. those that were not found in either digestion by BamHI or HindIII alone. Connecting the BamHI-HindIII fragments would allow linkage of the four BamHI fragments. HindIII digestion of the BamHI fragments, $B a-B d$, generated four new fragments of 18.5 , $14,11.5$ and $6.2 \mathrm{~kb}$ (Fig. 1), that did not correspond to any HindIII-digested bands of total phage DNA. When each of these four BamHI fragments was labelled and hybridized to a HindIII digest of phage DNA, all of the fragments hybridized to the $25 \mathrm{~kb}$ Ha fragment (data not shown). This implied that the $25 \mathrm{~kb} \mathrm{Ha}$ band consisted of two fragments of approximately $25 \mathrm{~kb}$ in size that were not resolved during electrophoresis. This was confirmed when BamHI was used to digest the $\mathrm{Ha}$ fragment purified from the HindIII-digested phage DNA; the four fragments, $18.5,14,11.5$ and $6.2 \mathrm{~kb}$, were released. Assuming that the $\mathrm{Ha}$ band was composed of two separate $25 \mathrm{~kb}$ fragments, the $\mathrm{Ha}$ fragment(s) was ligated into cosmid pJB8 and cloned into Escherichia coli HB101 (Fig. 2a). Digestion of a cosmid insert with BamHI released the 18.5 and $6.2 \mathrm{~kb}$ fragments. The $\mathrm{Ha}$ resulting from this clone was designated $\mathrm{Hal}(24.7 \mathrm{~kb})$. This result implied that the 18.5 and $6.2 \mathrm{~kb}$ fragments were linked (Fig. $2 a, b$ ). Because we concluded that there was the possibility that two different $25 \mathrm{~kb}$ fragments existed, the second fragment was designated $\mathrm{Ha} 2(25.5 \mathrm{~kb})$, which was assumed to contain the 14 and $11.5 \mathrm{~kb}$ fragments. We attempted to subclone the $\mathrm{Ha} 2$ fragment into a cosmid vector but were not able to obtain a clone containing the fragment corresponding to $\mathrm{Ha} 2$. Since the restriction enzyme data clearly indicated the existence of a second HindIII fragment, we concluded that $\mathrm{Ha} 2$ must be present in the original $\mathrm{Ha}$ fragment. By this method we established the relationship between $\mathrm{Ba}$ and $\mathrm{Bd}$ as well as that between $\mathrm{Bb}$ and $\mathrm{Bc}$.

\section{Two populations of phage DNA detected in $D$. vulgaris}

Although we were able to demonstrate the direct linking of $\mathrm{Ba}$ to $\mathrm{Bd}$ and $\mathrm{Bb}$ to $\mathrm{Bc}$, we could not establish the linking of the $\mathrm{Ba}-\mathrm{Bd}$ fragment to the $\mathrm{Bb}-\mathrm{Bc}$ fragment. We observed that when a purified $\mathrm{Ha}$ fragment

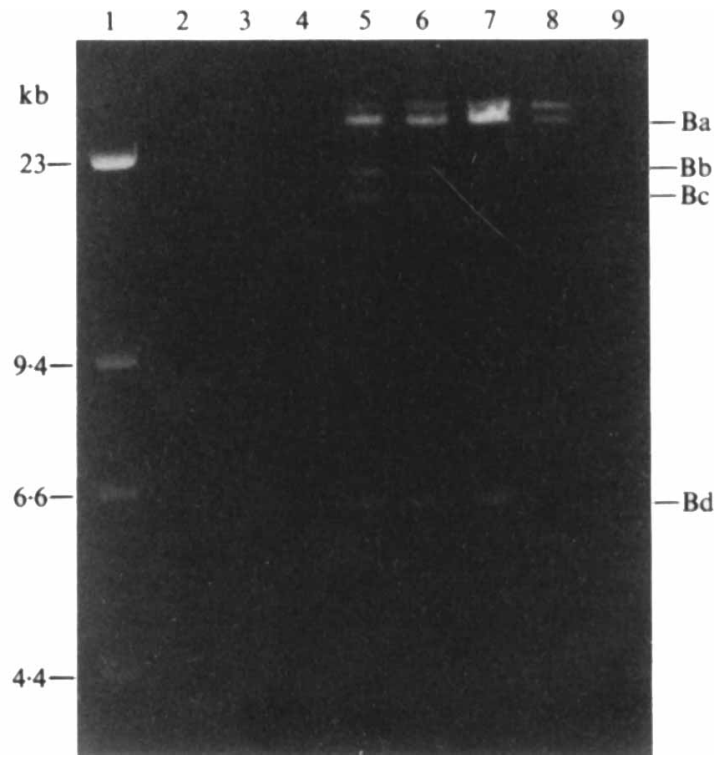

Fig. 4. BamHI restriction endonuclease pattern of phage DNA from D. vulgaris after fractionation on $\mathrm{CsCl}$ density gradient. Fractions containing DNA, as judged by $A_{260}$, were ethanol-precipitated, digested with $B a m H I$ and electrophoresed on $0.6 \%$ agarose gel. Lanes 2-9, BamHI-digested DNA in fractions with densities of $1.718,1.709$, $1.706,1.704,1.698,1.693,1.684$ and 1.679 , respectively. HindIIIdigested $\lambda$ phage DNA is shown in lane 1 .

$(\mathrm{Hal}+\mathrm{Ha} 2)$ was digested with BamHI, the resulting bands varied in intensity on the ethidium-bromidestained agarose gel. Careful examination of the digestion pattern indicated that the 18.5 and $6.2 \mathrm{~kb}$ bands (Hal) were always more intense than the 14 and $11.5 \mathrm{~kb}$ bands (Ha2). This intensity variation was also noticed in both the HindIII and BamHI digestion bands of total phage DNA. This observation implied that the Hal fragment was present in larger amounts in the $\mathrm{Ha}(\mathrm{Hal}+\mathrm{Ha} 2)$ band, and that the $\mathrm{Ha} \mathrm{l}$ and $\mathrm{Ha} 2$ arose from two different phage DNA molecules.

To determine if there were two types of phage DNA molecules present in our preparations, phage particles were further purified using a $\mathrm{CsCl}$ gradient. A bacteriophage DNA preparation was mixed in a $\mathrm{CsCl}$ solution at a final concentration of $1.72 \mathrm{~g} \mathrm{ml}^{-1}$ and centrifuged for $88 \mathrm{~h}$ in a Beckman $50 \mathrm{Ti}$ rotor at 38000 r.p.m. The resulting gradient was fractionated (in $100 \mu$ l fractions) and the $A_{260}$ and density of each fraction measured. The results reproducibly showed two peaks in the gradient at densities 1.704 and $1.693 \mathrm{~g} \mathrm{ml}^{-1}$. The DNA from each fraction was precipitated with ethanol, digested with BamHI, and separated by electrophoresis. Fig. 4, lane 7 clearly shows that $\mathrm{Bb}(21.9 \mathrm{~kb})$ and $\mathrm{Bc}(18.8 \mathrm{~kb})$ fragments, assumed earlier to be linked, were not present in the second peak. The first peak (corresponding to Fig. 4, lane 5), however, contained both DNA populations. Furthermore, the absence of the $\mathrm{Bb}$ and $\mathrm{Bc}$ fragments in 
Fig. 4, lane 7, is accompanied by higher intensity bands of $\mathrm{Ba}$ and $\mathrm{Bd}$ fragments. This strongly supported the conclusion that there were two different DNA populations in cultures of $D$. vulgaris NCIMB 8303. These results were consistently reproduced with three different gradients with different concentrations of $\mathrm{CsCl}$.

\section{Electron micrograph of D. vulgaris phage DNA}

Based on the size of the restriction enzyme fragments, the total size of each of the two phage DNA should be approximately $40 \mathrm{~kb}$. It was also of interest to us to determine whether the bacteriophage DNA was linear or circular. Electron micrographs of the phage DNA showed that the DNA was linear and, using the cosmid pJB8 as a reference molecule $(5.4 \mathrm{~kb})$, the size of the phage DNA molecule was estimated to be $40-41 \mathrm{~kb}$.

The infection of a bacterial cell by two unrelated bacteriophages is not unique to $D$. vulgaris. Superinfection by an unrelated phage has been documented in $E$. coli $\mathrm{K} 12$ in the case of T5 and $\lambda$ phage (Adams, 1959; Weigle \& Delbruck, 1951). The same phenomenon has been demonstrated with the unrelated temperate phages P1 and P8 in Pseudomonas aeruginosa 13 (Adams, 1959). In these studies, if the lysogenic strain 13 is induced with $\mathrm{UV}$ and then superinfected with $\mathrm{P} 1$, the majority of the bacteria liberate $\mathbf{P 1}$ and $\mathbf{P 8}$.

This study describes the first molecular characterization of a phage from a sulphate-reducing bacterium. The results strongly suggest that two different phages were induced from cultures of $D$. vulgaris NCIMB 8303. It is not clear whether these phages were released from the same cell and if so, what roles they play in infection, e.g. helper phage for each other. Further studies are necessary to address these questions.
We thank Ms S. Mason for preparation of this manuscript. This study was supported in part by grants AI-24115 and AI-30356 (to C.W.) from the National Institute of Allergy and Infectious Diseases, and by a grant from the University of Kansas General Research Fund.

\section{References}

ADAMS, M. H. (1959). Bacteriophages. New York: Interscience.

BRADLEY, D. E. (1967). Ultrastructure of bacteriophages and bacteriocins. Bacteriological Reviews 31, 230-314.

GARON, C. F. (1986). Ultrastructure techniques for microorganisms. In Electron Microscopy of Nucleic Acids, pp. 161-181. Edited by H. C. Aldrich \& W. J. Todd: New York: Plenum Press.

HaNDley, E. J., Adams, V. \& AKagi, J. M. (1973). Morphology of bacteriophage-like particles from Desulfovibrio vulgaris. Journal of Bacteriology 115, 1205-1207.

IsH-HOROWICZ, D. \& BURKE, J. F. (1981). Rapid and efficient cosmid cloning. Nucleic Acids Research 9, 2989-2998.

KAMIMURA, K. \& ARAKI, M. (1989). Isolation and characterization of a bacteriophage lytic for Desulfovibrio salexigens, a salt-requiring sulfate-reducing bacterium. Applied and Environmental Microbiology 55, 645-648.

Maniatis, T., Fritsch, E. F. \& Sambrook, J. (1982). Molecular Cloning: A Laboratory Manual. Cold Spring Harbor, NY: Cold Spring Harbor Laboratory.

Postgate, J. R. (1984). The Sulphate-Reducing Bacteria, 2nd edn. Cambridge: Cambridge University Press.

RAPP, B. J. \& WALL, J. D. (1987). Genetic transfer in Desulfovibrio desulfuricans. Proceedings of the National Academy of Sciences of the United States of America 8, 9128-9130.

SeYedirashti, S., WoOd, C. \& AKaGI, J. M. (1991). Induction and partial purification of bacteriophages from Desulfovibrio vulgaris (Hildenborough) and Desulfovibrio desulfuricans ATCC 13541. Journal of General Microbiology 137, 1545-1549.

Weigle, J. J. \& Delbruck, M. (1951). Mutual exclusion between an infecting phage and a carried phage. Journal of Bacteriology 62, 301318.

Westmoreland, B. C., SztbaksJu, W. \& Ris, H. (1969). Mapping of deletions and substitutions in heteroduplex DNA molecules of bacteriophage Lambda by electron microscopy. Science 163, 13431348. 